\title{
FEASIBILITY STUDY ON THE DEVELOPMENT OF REFERENCE
} MATERIAL OF PESTICIDE IN BLACK TEA

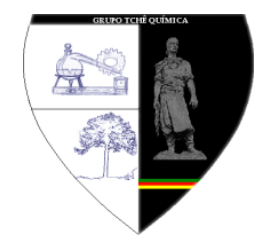

\author{
STYARINI, Dyah*; GUNLAZUARDI, Jarnuzi² \\ ${ }^{1}$ Metrology in Chemistry Research Group, Research Center for Chemistry Indonesian Institute of Sciences, \\ Kawasan Puspiptek, Serpong, Tangerang Selatan, Banten, Indonesia,15314
}

${ }^{2}$ Chemistry Department, Faculty of Mathematic and Natural Science, University of Indonesia, Depok, Indonesia, 16424

${ }^{*}$ Corresponding author.

e-mail: dyah.styarini@lipi.go.id

Received 31 March 2015; received in revised form 21 August 2016; accepted 01 September 2016

\section{RESUMO}

Neste artigo, é relatado um estudo sobre o desenvolvimento de material de referência (RM) para aendossulfan e bifentrina no chá preto como matriz. O estudo foi conduzido com base no facto de que tais RMs não estavam actualmente disponíveis na Indonésia. Para obter um bom e adequado RM, um estudo de viabilidade e desenvolvimento de RM é extremamente necessário. O RM foi primeiramente preparado por moagem da folha de chá para ter um tamanho de partícula de cerca de 150-106 $\mu \mathrm{m}$ e um teor de água de cerca de $5,99 \%$. Uma pequena porção da folha de chá triturada foi então cravada com solução de hexano contendo ambos os analitos alvo a certas concentrações, seguida por uma secagem apropriada para obter o candidato inicial de RM (iCRM). O iCRM foi então bem misturado apropriadamente com outra porção de material de chá moído não cravado para obter o candidato do pó de material de referência final (fCRM). Uma cromatografia gasosa equipada com detector de captura de elétrons foi utilizada para a identificação de analitos e a viabilidade do método foi avaliada em termos de técnica de espícula e processo de homogeneização. A avaliação por ANOVA mostrou que o fCRM foi estatisticamente considerado homogêneo e apresentou fração de massa de $\alpha$-endossulfan e bifentrina $\pm U$ de $380,32( \pm 120,32) n g$ g-1 e 522,74 $( \pm 148,65)$ ng $\mathrm{g}-1$, respectivamente .

Palavras-chave: Material de referência, a-endossulfan, Bifentrina, Chá, Spiking

\section{ABSTRACT}

In this paper, a study on development of reference material (RM) for a-endosulfan and bifenthrin in black tea as a matrix is reported. The study was conducted on the basis that such RMs was presently not available in Indonesia. To obtain a good and proper RM, a feasibility study of RM development is extremely required. The RM was firstly prepared by grinding the tea leaf to have particle size of about 150-106 $\mu \mathrm{m}$ and water content of about $5.99 \%$. A small portion of the grinded tea leaf was then spiked with hexane solution containing both target analytes at certain concentrations, followed by a proper drying to obtain initial candidate of RM (iCRM). The iCRM was then well-mixed properly with another portion of non-spiked grinded tea material to get final candidate reference material (fCRM) powder. A gas chromatography equipped with electron capture detector was used for analyte identification and the feasibility of the method was evaluated in term of spiking technique and homogenization process. The evaluation by ANOVA showed that fCRM was statistically considered to be homogeneous and having $\alpha$-endosulfan and bifentrin mass fraction $\pm U$ of $380.32( \pm 120.32) \mathrm{ng}$ $\mathrm{g}^{-1}$ and $522.74( \pm 148.65) \mathrm{ng} \mathrm{g}^{-1}$ in dry weight basis, respectively.

Keywords: Reference material, $\alpha$-Endosulfan, Bifenthrin, Tea, Spiking 


\section{INTRODUCTION}

Pesticide is widely applied in tea plantation area to protect the plant from the pests. Nonetheless, the pesticide residues in tea products then become an important issue in world tea trade. Various quality standards or regulations concerning the quality of tea products have been set and applied in both national and international level to keep the quality and safety of the tea product, as well as to set the selling price. The maximum residue limit (MRL) value of pesticide in tea is one of the parameters which is defined in quality standards. It is intended to protect the tea's consumers from the harm of any pesticide residues. In Indonesia, the MRL values for some pesticides residues in tea has been regulated as described in the National Standard of Indonesia (SNI) (SNI, 2008).

In the area of pesticide residues testing, the accuracy of a measurement is an important parameter. The accurate results could keep the quality of the tea products, which further protect human from exposure to harmful pesticide residues. Practically, however, some difficulties related to the pesticide residues analysis in tea products have been found because some residues may present up to sub-ppm levels while matrix being analyzed was very complex. In this regards, it was experimentally evident from an international proficiency testing program organized by Asia Pasific Metrology Programme (APMP), by which our lab has taken a part. From the result of PT evaluation, it was found that the consensus value of the participant's data was not good enough (Dayarathna et al., 2013), implying that the complexity of the sample matrix could be the most possible reason for the unexpected results.

High accuracy and comparability of chemical measurement results are of very important for a fair and society protection action and those can be achieved when aspects of quality control or quality assurance (QC/QA) system for testing laboratory are fulfilled (Robert, 2007; Franz, 2006). Certified reference material (CRM) is one of QC/QA aspect that contribute to the reliability and comparability measurement result between testing laboratories.

Reference material (RM) is defined as "material or substance one or more of whose property values are sufficiently homogenous and well established to be used for the calibration of an apparatus, the assessment of a measurement method, or for assigning values to materials". While CRM is defined as "Reference materials, accompanied by a certificate, which has one or more properties whose value is certified by a procedure that establishes traceability to the accurate realisation of the unit in which the values of the properties are expressed, and for which each certified value is accompanied by a stated uncertainty with a given level of confidence" (ISO Guide 30, 1992; ISO, 1993). Traceability itself as currently defined according to VIM is a "property of the result of a measurement or the value of a standard whereby it can be related to stated references, usually national or international standards, through an unbroken chain of comparisons all having stated uncertainties". Traceable measurement results, accompanied with their associated measurement uncertainty, form the most solid basis for comparability of results at national or international level. Realize the importance of reference material (RM) for testing laboratories and the lack of matrix RM containing pesticide in Indonesia, the feasibility study for the development of reference material for pesticide in black tea matrix has been conducted to address the needs.

Based on ISO Guide 35, there are several steps have to be carefully carried out on the preparation of the CRM. The major steps are selection of raw material, feasibility studies, short and long term stability study, characterization of the candidate RM with respect to the targeted properties, assignment of the certified values and their uncertainty, drafting a certificate and certification report and reviewing of the project results and approval of the certification documents (ISO Guide 35, 2006; Hendrik et al., 2006). In this regards, several studies have been previously reported for the preparation of pesticide reference materials in food matrix such as cucumber and cabbage (Susana et al., 2015; Seonghee et al., 2011). Taking into account the important such feasibility study, in this works, the evaluation were focused on the spiking techniques and homogeneity for the preparation of reference materials for pesticides ( $\alpha$ endosulfan and bifenthrin) in black tea matrix. Practically, to obtain a sufficient homogenous solid material containing target analytes by using 
a spiking technique is quite difficult. In this regrads, the way how to spike the target analyte into solid material and the technique of the homogenization process need to be optimized. Once the optimized procedure for spiking and homogenization technique obtained, then it can be applied for the preparation of the reference material.

\section{MATERIAL AND METHODS}

\subsection{Materials}

The pesticide standards used were $\alpha$ endosulfan (NMIA, Australia, $>99 \%$ purity) and bifenthrin (Chem. Service West Chester, USA, > $99.1 \%$ purity). The organic solvents used in preparation of standard solutions and sample preparation were obtained from Merck, Germany including acetone (Suprasolve), diethyl ether (p.a grade), and n-hexane (EMSURE for analysis). Florisil (Merck, Germany) with particle size of $0.150-0.250 \mathrm{~mm}$ and $\mathrm{pH}$ 9-10 was used as sorbent in clean up procedure. Florisil was firstly activated in an oven at $130^{\circ} \mathrm{C}$ for 18 hours before used. Sodium sulfate anhydrous was used as drying agent. The black tea used as sample matrix was obtained from traditional market in Indonesia. Helium (Ultra High Purity) and Nitrogen (High Purity) were used as carrier gas and make up gas in GC- $\mu$ ECD system, respectively.

\subsection{Instrumentation}

Gas chromatography equipped with electron capture detector (GC-ECD, Hewlett Packard 6890) was used for pesticides measurement. The separation of pesticides component was conducted on a DB-5 capillary column $(30 \mathrm{~m} \times 0.25 \mathrm{~mm}$ I.D.x $0.25 \mu \mathrm{m})$. The helium gas carrier gas was used with flow rate of $1 \mathrm{~mL} / \mathrm{min}$. The injector port and detector temperature were kept at 250 and $300^{\circ} \mathrm{C}$, respectively. The oven temperature was programmed from $120^{\circ} \mathrm{C}$ for $1 \mathrm{~min}$ and was then followed by $25^{\circ} \mathrm{C} / \mathrm{min}$ ramping to $250^{\circ} \mathrm{C}$ and held for $5 \mathrm{~min}$ before ramped up to $300^{\circ} \mathrm{C}\left(5^{\circ} \mathrm{C} / \mathrm{min}\right)$ and held at this level for 2 min. Splitless injection mode with splitless time 0.75 min was applied. Nitrogen gas (high purity grade) at $60 \mathrm{~mL} / \mathrm{min}$ of flow rate was used as make up gas.

\subsection{Procedure of processing material}

\subsubsection{Matrix preparation}

The black tea used as matrix in this feasibility study was bought from traditional market. A series of powdered black tea with different in particle size were obtained by grinding the black tea sample followed by sieving with different size of siever including 250, 150, 106, and $45 \mu \mathrm{m}$.

\subsubsection{Preparation of pesticide standard solution}

Approximately $65 \mathrm{ml}$ of a n-hexane solution containing both $0.375 \mathrm{mg}$ a-endosulfan and $0.597 \mathrm{mg}$ bifenthrin was prepared and then was used for spiking $1 \mathrm{~kg}$ of black tea. The high precision balances were calibrated before use by using international traceable standards.

\subsubsection{Spiking, homogenization, and storage}

A certain amount $(50 \mathrm{~g})$ of powdered black tea was taken from $1 \mathrm{~kg}$ stock followed by soaking in $65 \mathrm{ml}$ of pesticide standard solution. The solvent was then evaporated untill initial dry spiked black tea was obtained (denoted as iCRM). The iCRM was mixed with another $50 \mathrm{~g}$ of unspiked powdered black tea, giving $100 \mathrm{~g}$ of spiked black tea. After that, the $100 \mathrm{~g}$ of spiked black was then mixed with another $100 \mathrm{~g}$ of unspiked black tea to get $200 \mathrm{~g}$ of homogenous spiked black tea. A similar procedure was continuously applied so that $1 \mathrm{Kg}$ of final candidat spiked black tea was obtained (denoted as fCRM). Furthermore, the fCRM was manually homogenized. The total homogenization process took about $10 \mathrm{~h}$. This fCRM was then divided into 50 portion with $20 \pm 1 \mathrm{~g}$ for each and all were packed to get 50 amber bottles. All these amber bottles were labeled and sequently numbered. The packed fCRM were then stored in the freezer at temperature of $-15^{\circ} \mathrm{C}$, before used for analysis.

\subsection{Analytical method for Characterization}

A validated pesticide residue test method was used for analysis and homogeneity testing. The analytical method used in this study was adapted from Styarini, et.al., 2014 with slightly modification in the extraction procedure. Typically, a certain amount $(2 \mathrm{~g})$ of spiked black tea sample containing target pesticide residues 
was transferred into an Erlenmeyer and then extracted using $60 \mathrm{ml}$ of acetone/n-hexane (by mixing $20 \mathrm{ml}$ of acetone with $40 \mathrm{ml}$ of $\mathrm{n}$-hexane). After overnight maseration at room temperature, the mixture was centrifuged to separate the filtrate and tea sample. The filtrate obtained was evaporated using evaporation flask until near to dryness. The residue obtained was subjected to a clean-up procedure by dissolving such residue into n-hexane and the solution was then pour into activated florisil column. The pesticide residues in the florisil column were eluted by $100 \mathrm{ml}$ of mixture of $\mathrm{n}$-hexane/diethyl ether (85/15) (v/v) and the eluate was collected into a conical evaporating flask and then concentrated under vacuum condition untill near to dryness. The residue was then re-dissolved in approximately 1 $\mathrm{ml}$ of $\mathrm{n}$-hexane as final solution. A quantitative analysis of both $\alpha$-endosulfan and bifenthrin residues was done by injecting $2 \mu \mathrm{l}$ of final solution to the GC- $\mu E C D$. An external calibration method was applied for the quantitation.

\subsection{Homogeneity study}

In this study, 8 bottles were randomly picked and used in the homogeneity study. The analysis of those 8 samples was done in triplicate. The sample homogeneity was statistically evaluated using ANOVA technique.

\section{RESULT AND DISCUSSION}

\subsection{Preparation of black tea as a matrix}

Figure 1 shows five groups of particle size distribution of the black tea used as matrices in this study. It can be seen from Fig. 1, the most abundant particle size obtained was between 45 $-106 \mu \mathrm{m}$.

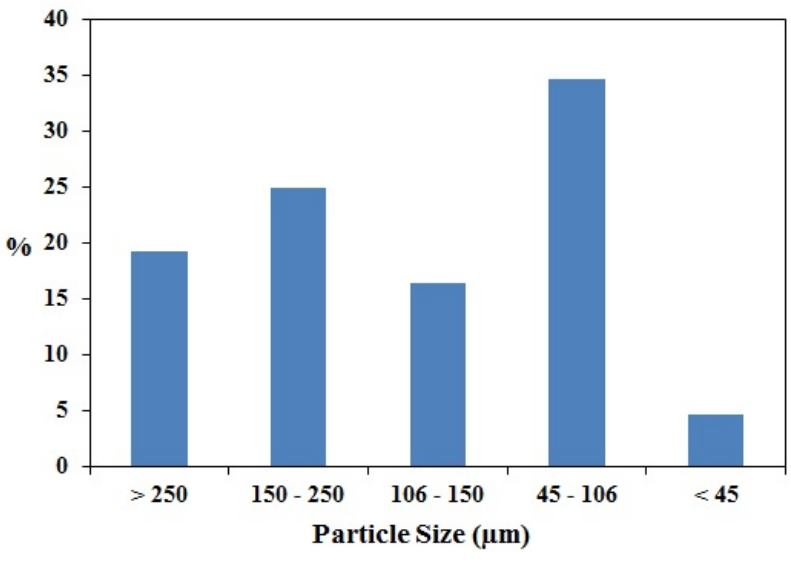

Figure 1. The distribution of particle size of black tea as matrix (for interpretation of the references to color in the figure, the reader is referred to the web version of the articles).

The sieveing process was conducted to obtain the homogenous particle size of the tea material after grinded. It would be expected that the preparation of material from a homogenous particle size could be easier than other no homogenous materials. In this study, the tea powder having particle size between 106 and 150 $\mu \mathrm{m}$ was choosen as material for preparing candidate of RM.

The water content of the tea matrix is an important factor to be characterized. High water content of tea matrix may increase the risk of inhomogeneity due to the matrix can be coagulated easily. The water content of the tea material was determined by gravimetric method (a common drying method) using oven at $105^{\circ} \mathrm{C}$. The value of CRM is normally certified in dry mass fraction basis, showing that the moisture content (in dry mass fraction) of a candidate RM is critically important to be used in the calculation of the value of the target analytes (Siegfrid, K. et al., 2000). For water content determination, the quantitative analysis were performed in 7 replicate. It was found that the average of water content of the black tea material was $5.99 \%$, indicating that the black tea material was dry enough. Generally speaking, characteristic of the tea material used in this study with uniform in particle size and low water content indicated that a high level of homogeneity of candidate RM has been achieved. 


\subsection{Method of Quantification and validation}

It has been well recognized that the tea matrix is very complex material containing pigments such as chlorofill and carotenoid, as well as flavor compounds, polifenol and cafein. All these substances may become interference during GC quantitation. It has been previously reported that the black tea matrix is more complex than the green tea due to its higher content of volatile compounds (Juniaty, 2013; Sussane, 2014). Nonetheless, the selective extraction method and clean up procedure can minimize such possible interferences. Besides, the operational condition of the GC system is also important for achieving an accurate result of analysis. In respect to $\alpha$-endosulfan and bifentrin, the validation results indicated that the analytical method using GC- $\mu$ ECD can separate those two target analytes very well. As shown in Figure 2, the retention time of $\alpha$-endosulfan and bifenthrin were found to be 8.66 and $11.71 \mathrm{~min}$, respectively.

Moreover, the method used was also found to be good in term of its recovery and precision. The recovery values for a-endosulfan and bifenthrin were found to be 77.34 and 96.18 $\%$, while the precision values (\% RSD) were found to be 17.60 and $16.09 \%$, for the $\alpha$ endosulfan and bifenthrin, respectively.

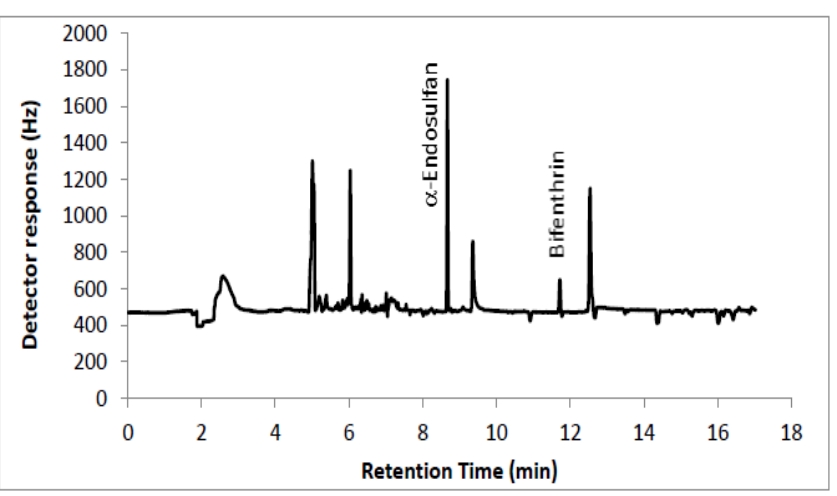

Figure 2. Chromatogram of $\alpha$-endosulfan and bifenthrin in tea matrix

For quantitation of the mass fraction of $\alpha$ endosulfan and bifenthrin the Equation 1 was used,

$$
X=\frac{C_{x} \cdot W_{1} \cdot W_{2}}{W_{3} \cdot W_{2} \cdot W_{s}} \times \frac{1}{1-M} \times \frac{1}{\operatorname{Re} c}
$$

where $X$ is the mass fraction of analyte, $C_{x}$ was the concentration of the analyte in the extract injected to the GC system derived from calibration curve. The $W_{1}, W_{2}, W_{3}$ and $W_{s}$ are the mass of solution after addition of $10 \mathrm{ml}$ of $\mathrm{n}$ hexane, the mass of solution taken for clean-up procedure, the mass of final solution in $1 \mathrm{ml}$ of 1 $\mathrm{ml}$ of $\mathrm{n}$-hexane, and the mass of tea sample used in the analysis, respectively. $\mathrm{M}$ and $\mathrm{Rec}$ are the water content and the recovery, respectively, and both were used as the correction factor.

\subsection{Spiking}

In this feasibility study, the spiking technique was used in preparing the candidate RM. According to ISO Guide 35, a major problem with spiking is the achievement of sufficient homogeneity and stability of the candidate RM. In a word, a sufficient homogeneity and stability of a candidate RM can be achieved by applying a proper spiking method (ISO Guide 35, 2006). Based on ISO Guide 35, the most suitable spiking method for a solid material is an incipient wetness' technique. In this regards, the component to be spiked is dissolved in a suitable amount of solvent where the volume of solvent used is only sufficient to completely wet the surface of the solid. In this study, two kinds of solvents, n-hexane and acetone were used for soaking the tea material in the pesticide standards solution. These two solvents were choosen because the target analytes can be welldissolved in both solvents and the results were then compared. In this study, optimization of the solvent volume $(\mathrm{ml})$ was firstly conducted. An optimum of solvent volume is the volume needed to soak about $50 \mathrm{~g}$ of tea material perfectly. Two portions of $50 \mathrm{~g}$ of tea materials were soaked in acetone and $n$-hexane, respectively. After a few time idle, the solvent was then evaporated. From Fig. 3, it can be seen that the wall of the evaporating flask for soaking the tea material with acetone was covered by strong green crust color which is characteristic for the matrix of tea, while weak green crust was observed in the wall of the evaporating flask used for soaking the tea material with $n$-hexane. From this finding, the non polar solvent, n-hexane was used for further for dissolving the standards of $\alpha$-endosulfan and bifenthrin. The $n$-hexane solution containing the pesticide standards was used to soak the black tea material. 


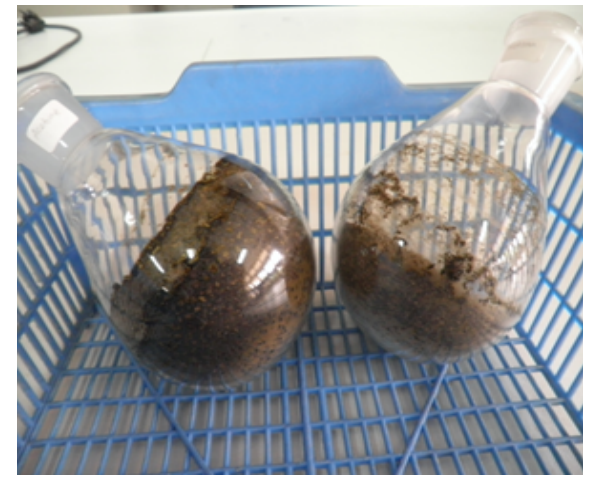

Figure 3. The evaporation results after tea material soaking with $A$ ) acetone and $B$ ) $n$-hexane (for interpretation of the references to color in the figure, the reader is referred to the web version of the articles).

In this study, at about $65 \mathrm{ml}$ of pesticide standard solution in n-hexane was needed to wet all surface of about $50 \mathrm{~g}$ of the black tea material. Theoretically, $50 \mathrm{~g}$ of spiked black tea will contain approximately $7890 \mathrm{ng} \mathrm{g}^{-1}$ and $12704 \mathrm{ng} \mathrm{g}^{-1}$ of $\alpha$ endosulfan and bifenthrin respectively. After evaporation of the n-hexane at $600 \mathrm{mbar}$ and $40^{\circ} \mathrm{C}$, a dry spiked tea sample, so called as initial Candidate Reference Material (iCRM), was achieved. The iCRM was analyzed using the GC$\mu \mathrm{ECD}$ in duplicate to check the concentration of the target analytes in iCRM. The result showed that the average concentration for a-endosulfan and bifenthrin were considered to close to the theoretical value as shown in Table 1. Hence, it can be concluded that the value obtained from GC-ECD analysis was comparable to that of theoretical value.

Table 1. Analysis result of iCRM

\begin{tabular}{ccc}
\hline Compound & $\begin{array}{c}\text { Mass fraction in } \\
\text { iCRM } \\
\left(\mathrm{ng} \mathrm{g}^{-1}\right)\end{array}$ & $\begin{array}{c}\text { Theoretical } \\
\text { value in iCRM } \\
\left(\mathrm{ng} \mathrm{g}^{-1}\right)\end{array}$ \\
\hline $\begin{array}{c}\alpha- \\
\text { endosulfan } \\
\text { Bifentrin }\end{array}$ & 6080.81 & 7890 \\
\hline
\end{tabular}

Moreover, to increase the homogeneity, the iCRM was poured into evaporation flask followed by rotating at rotary evaporator for 6 hours at room temperature and room pressure, Afterwards, $950 \mathrm{~g}$ unspiked black tea was gradually transferred into evaporation flask containing iCRM. The rotating process was continued untill the unspike black tea was totally mixed with the iCRM. and then the final Candidate Reference Material (fCRM) was obtained. After homogenization for 10 hours, the fCRM was analyzed in triplicate to check its homogenity property.

The analysis results showed that the average value for both target analytes in the fCRM (Table 2) were close to the theoretical values. The theoretical values for $\alpha$-endosulfan and bifenthrin were found to be about $375 \mathrm{ng} \mathrm{g}^{-1}$ and $597 \mathrm{ng} \mathrm{g}^{-1}$, respectively. However, high values of measurement repeatability for both target analyte (Table 2) were still observed. The analysis result implies that the homogenization process was found to be good enough. However, an additional homogenization process was still required needed to increase the homogeneity of the fCRM. Therefore, the additional homogenization was carried out for about 1 hour. Finally, the homogenized fCRM was packed by transferring a certain amount $(20 \pm 1 \mathrm{~g})$ into a capped amber bottle. For study purpose, a fifty capped amber bottles containing the homogenized fCRM were prepared for this study.

Table 2. Analysis result of fCRM before packed in to the bottles

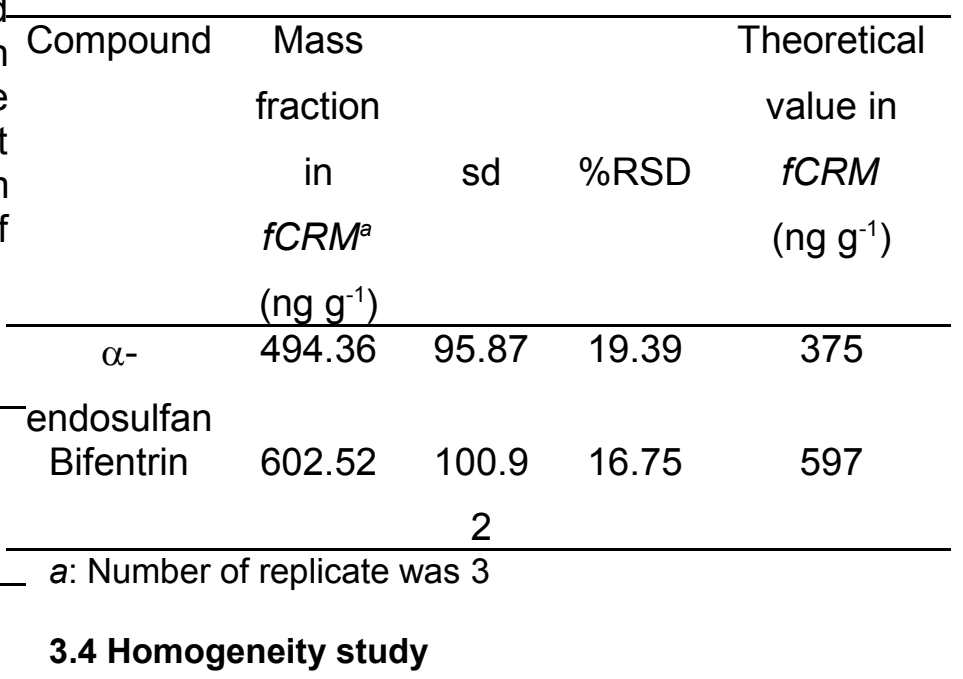

As mentioned above, homogeneity and stability are crusial factor in CRM preparation. For the homogeneity study of fCRM, 8 amber bottles containing fCRM prepared above were randomly taken and analysed in triplicate. The results of GC- $\mu E C D$ analysis were statistically evaluated using Analysis of variance (ANOVA). It was 
statistically found that the $F_{\text {crit }}$ value at 95\% confidence level for $\alpha$-endosulfan and bifenthrin were 2.66 for both, while the $F_{\text {calculated }}$ value were found to be 0.32 and 1.75 for $\alpha$-endosulfan and bifenthrin respectively. By comparison, the $F_{\text {calculated }}$ value for both target analyte were smaller than that of the $F_{\text {crit }}$ value $\left(F_{\text {calculated }}<F_{\text {crit }}\right)$, indicating that there was no significant difference among these 8 the different bottles. Hence, the materials is considered as sufficiently homogenous at confidence level of $95 \%$. The analysis result of the homogeneity test both for $\alpha-$ endosulfan and bifenthrin are presented in Fig. 4. In addition, the average of mass fraction values obtained from the triplicates analysis of 8 different units of bottle for $\alpha$-endosulfan and bifenthrin were found to be 380.32 and $522.74 \mathrm{ng} \mathrm{g}^{-1}$, respectively.
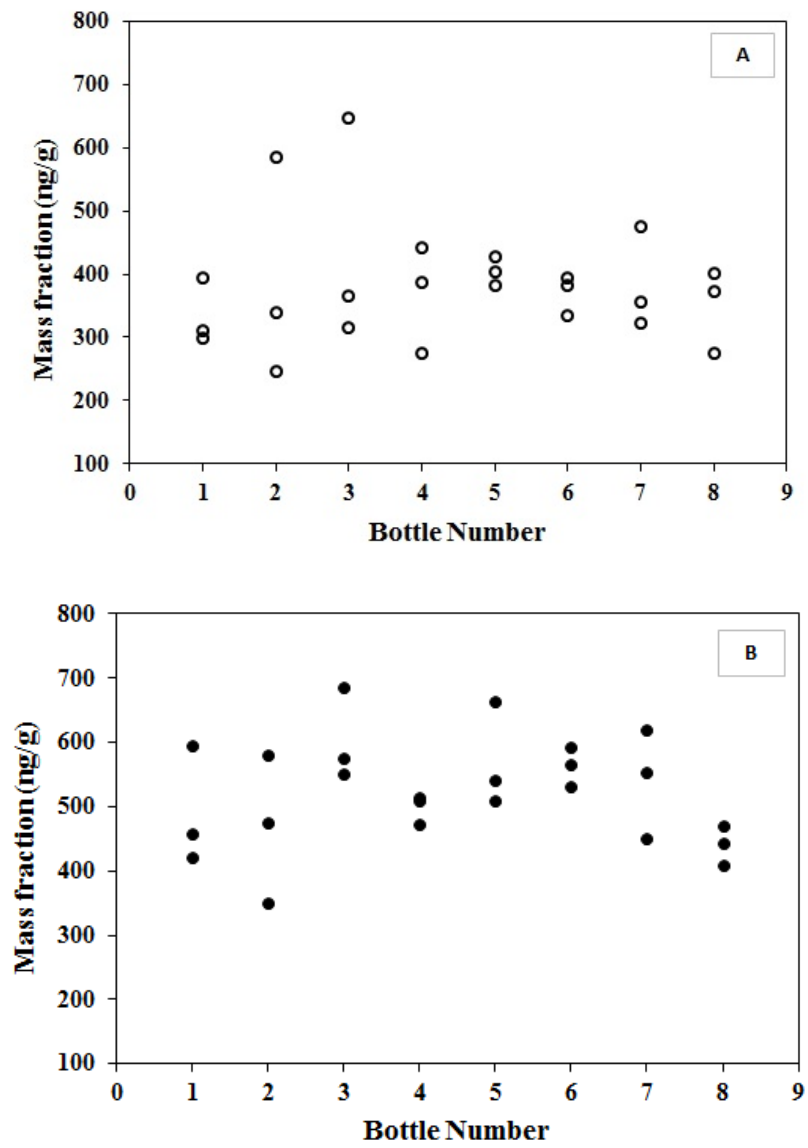

Figure 4. The analysis result of homogeneity test for A) $\alpha$-endosulfan and B) Bifenthrin

\subsection{Estimation of Uncertainty}

The uncertainty value of the measurement $\left(U_{\text {measure }}\right)$ was calculated by using bottom-up approach as described in Eurachem
(Eurachem/Citac Guide, 2012). The uncertainty sources of the measurement result (Table 3 ) were derived from the components in the calculation equation (Eq. 1). Figure 5 presents the average values obtained from triplicate analysis of each bottles and their uncertainty for both $\alpha$-endosulfan and bifenthrin. Moreover, standard uncertainty for the characterisation process $\left(u_{\text {char }}\right)$ for $\alpha$-endosulfan and bifenthrin were found to be $48.72 \mathrm{ng} \mathrm{g}^{-1}$ and $64.63 \mathrm{ng} \mathrm{g}^{-1}$, respectively.

Table 3. The sources of uncertainty of the measurement result for calculating $u_{c h a r}$

\begin{tabular}{|c|c|c|}
\hline Symbol & Source of uncertainty & Unit \\
\hline $\mathrm{X}$ & Concentration of analyte & $\mathrm{ng} / \mathrm{g}$ \\
\hline & $\begin{array}{l}\text { in the sample (dry base) } \\
\text { Concentration of analyte }\end{array}$ & $\mathrm{ng} / \mathrm{g}$ \\
\hline \multirow{2}{*}{$C_{x}$} & in the final solution & \\
\hline & injected to GC (from & \\
\hline $\mathrm{C}_{\text {middle }}$ & $\begin{array}{l}\text { calibration curve) } \\
\text { Middle standard solution }\end{array}$ & $\mathrm{ng} / \mathrm{g}$ \\
\hline \multirow[t]{2}{*}{$W_{1}$} & $\begin{array}{l}\text { in the calibration curve } \\
\text { The mass of solution }\end{array}$ & g \\
\hline & after addition of $10 \mathrm{~mL}$ of & \\
\hline \multirow[t]{3}{*}{$W_{2}$} & $\begin{array}{l}n \text {-hexane } \\
\text { The mass of solution }\end{array}$ & g \\
\hline & taken for clean up & \\
\hline & procedure $(3 \mathrm{~mL})$ & \\
\hline$W_{3}$ & $\begin{array}{l}\text { solution in } 1 \mathrm{~mL} \text { of } \mathrm{n} \text { - } \\
\text { hexane }\end{array}$ & $g$ \\
\hline$W_{s}$ & The mass of tea sample & g \\
\hline \multirow[t]{2}{*}{$\begin{array}{c}\operatorname{Rec} \\
M\end{array}$} & $\begin{array}{l}\text { used in the analysis } \\
\text { Recovery of the method } \\
\text { Water content of the }\end{array}$ & $\begin{array}{l}\% \\
\%\end{array}$ \\
\hline & $\begin{array}{l}\text { sample } \\
\text { Presision of the method }\end{array}$ & - \\
\hline
\end{tabular}

ISO Guide 34 requires that in assigning the uncertainties for the property values of interest, any uncertainties resulting from between unit variations and/or from possible instabilities (both during storage and during transportation) shall be included (ISO Guide 34, 2000). It means that the uncertainty of the CRM not only from the 
batch characterisation $\left(\mathrm{u}_{\mathrm{char}}\right)$, but also from possible between bottle variation $\left(u_{b b}\right)$, instability upon long term storage $\left(u_{t t s}\right)$ and instability during transport to the customer ( $\left.u_{\text {sts }}\right)$ (Thomas, P.J.L., et al., 2001). For the $u_{\text {char, }}$ the source of uncertainty is originated from the components in the measurement. The calculation results showed that the average concentration and the $u_{\text {char }}$ of both $\alpha$-endosulfan and bifenthrin for each unit bottle analyzed were overlap one to another, as shown in Figure 5.

Moreover, the standard uncertainty originated from between bottle variation $\left(\mathrm{u}_{\mathrm{bb}}\right)$ was calculated by using equation 2 and 3 .

$$
u_{b b}=\sqrt{\frac{M S_{\text {between }}-M S_{\text {within }}}{n_{\text {replicatesperunit }}}}
$$

From the calculation, it was found that the value of $u_{b b}$ for bifenthrin was $36.67 \mathrm{ng} g-1$. For $\alpha$ endosulfan, the value of $\mathrm{MS}_{\text {between }}$ was smaller than $\mathrm{MS}_{\text {within, when }} \mathrm{MS}_{\text {between }}$ is equal or smaller then $\mathrm{MS}_{\text {within }}$, then for the alternative, ubb' can be estimated by using Eq. 3, where $n$ is number of replicate and df is degrees of freedom of $\mathrm{MS}_{\text {within. }}$.

$$
u_{b b^{\prime}}=\sqrt{\frac{M S_{\text {within }}}{n}} \sqrt[4]{\frac{2}{d f}}
$$

(Eq. 3)

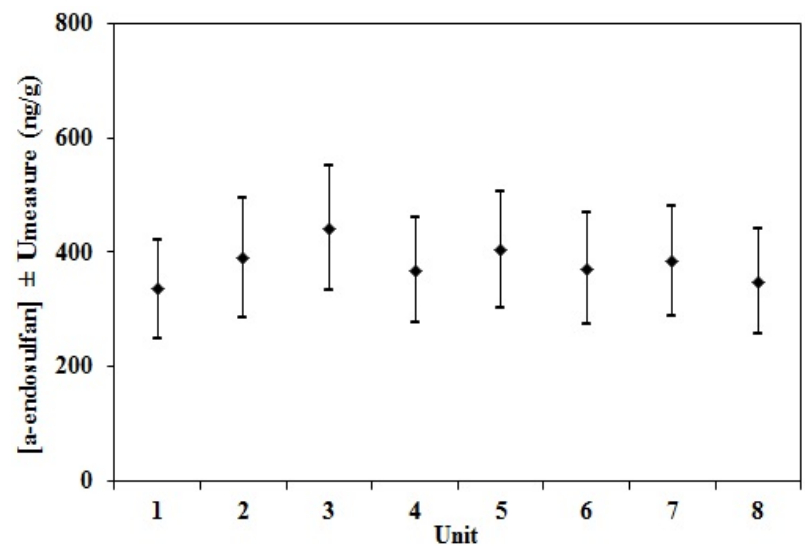

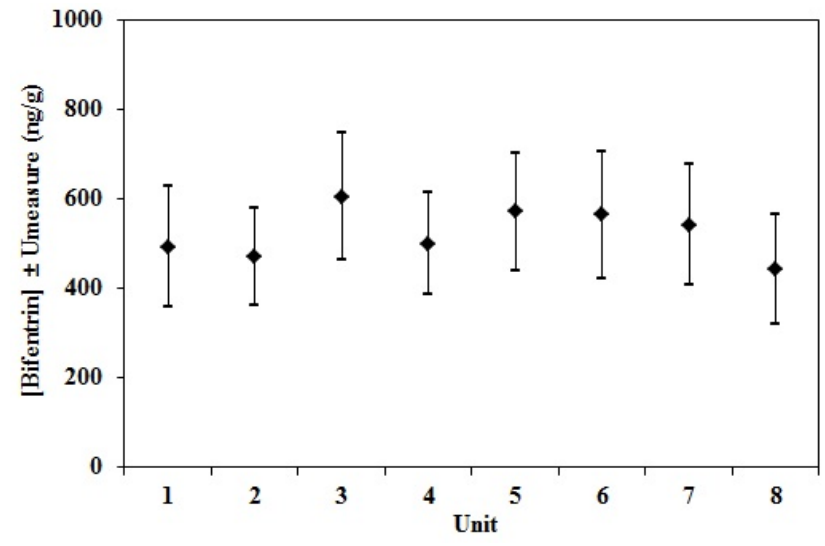

Figure 5. The average concentration of $\alpha$ endosulfan and bifenthrin accompanied with the $U_{\text {char }}$ values for both analytes in each unit bottles analyzed in the homogeneity test

The $u_{b b}$, value for a-endosulfan obtained from the calculation by using Eq. 3 was found to be $35.3 \mathrm{ng} \mathrm{g}^{-1}$. The expanded uncertainty $(U)$ value generated from the characterization and the homogeneity at coverage factor $(k)$ of 2 was then calculated using the following equation:

$$
U=2 \sqrt{u_{\text {char }^{2}}+u_{b b^{2}}}
$$

The $\mathrm{u}_{\mathrm{char}}$ and $\mathrm{u}_{\mathrm{bb}}$ for $\alpha$-endosulfan and bifenthrin were about $12 \%$, while the relative expanded uncertainty $(U)$ for both target analytes were found to be about $30 \%$. These results are summarized in Table 4.

Table 4. Summarize of mass fraction, expanded uncertainty of the $\mathrm{fCRM}$, and relative uncertainty of characterization $\left(u_{c h a r}\right)$ and homogenity $\left(u_{b b}\right)$.

\begin{tabular}{lcc}
\hline & $\alpha$-Endosulfan & Bifethrin \\
\hline $\begin{array}{l}\text { Mass fraction } \\
\left(\mathrm{ng} \mathrm{g}^{-1}\right)\end{array}$ & 380.32 & 522.74 \\
Expanded & 120.32 & 148.65 \\
uncertainty & & \\
$(\mathrm{U})\left(\mathrm{ng} \mathrm{g}^{-1}\right)$ & & \\
Relative U (\%) & 31.64 & 28.44 \\
$u_{\text {char }}(\%)$ & 12.81 & 12.36 \\
$U_{b b}(\%)$ & 9.28 & 7.02 \\
\hline
\end{tabular}




\section{CONCLUSION}

The feasibility study for the development of reference material for organochlorine pesticide ( $\alpha$-endosulfan) and pyrethroid (bifenthrin) in black tea by employing spiking technique has been conducted. The spiking of $\alpha$-endosulfan $(0.375$ $\mathrm{mg}$ ) and bifenthrin $(0.597 \mathrm{mg})$ were performed in the $1 \mathrm{Kg}$ of black tea. The result of the characterization showed that the spiked black tea (fCRM) have mass fraction $\pm \mathrm{U}$; $380.32 \pm 120.32$ $\mathrm{ng} \mathrm{g}^{-1}$ and $522.74 \pm 148.65 \mathrm{ng} \mathrm{g}^{-1}$ (in dry base) for $\alpha$-endosulfan dan bifenthrin, respectively. Based on the ANOVA result from the homogenity study, there were no statistically significant difference between 8 bottles; thus, the fCRM were considered to be sufficiently homogenous. The spiking technique was good and successful applied in this study. One can be noticed from this study is that the successful spiking technique applied is promising to be utilized in the future work for the preparation of CRM for pesticide residue in black tea at a larger scale. Besides the pesticide in tea RM could be used as quality assurance tool in the method validation for testing laboratories in Indonesia.

\section{Acknowledgement}

The authors would like to express gratitude to Research Center for Chemistry, Indonesian Institute of Sciences (RCChem-LIPI) for funding and supporting of facilities in performing this research. We would like also to express our gratitude and appreciate to Dr. Julia Kantasubrata, for her valuable advices and for the fruitful discussion. We also thank to Mrs. Sajekti Eka, Mrs. Nurhani Aryana, M.Si., Mr. Yosi Aristiawan, S.Si. and Mr. Sujarwo, S.Si., for the support in this research project. The authors very grateful to Dr. Oman Zuas, RCChem-LIPI, for critically manuscript reading and for his valuable comments.

\section{REFERENCES}

1. Dayarathna, D.; Thirimanna C.; Mubarak, A.; Mackay, L.; Rogerson, J.; tang, H.; Feng, J.; Sin, D.W.M.; and Wong, Y-C., Food Res. Int., 2013, 53 (2), 931-937.

2. EURACHEM/CITAC Guide, 2012, Quantifying Uncertainty in Analytica Measurement, third edition.

<http://www.citac.cc/QUAM2012_P1.pdf>

3. Franz, U., Anal Bioanal Chem., 2006, 386:1121-1136.

4. Hendrik, E., Andrea, H., and Franz, U., Pure Appl. Chem., 2006, vol. 78, No.1, pp. 135143.

5. International Organization for Standardization, 1992, ISO Guide 30:1992, ISO, Geneva, Switzerland.

6. International Organization for Standardization, 1993, International Vocabulary of Basic and General Terms in Metrology (VIM), 2nd edition, Geneva, Switzerland.

7. ISO Guide 35, 2006, Reference materials General and statistical principles for certification, third edition.

8. ISO Guide 34,2000 , General requirements for the competence of the reference material producers, second edition.

9. Juniaty, T.; and Balittri, Warta Penelitian dan Pengembangan Tanaman Industri, 2013, Volume 19 No.3, pp. 12-16.

10. Robert, K., Accred Qual Assure, 2007, 12:435-437.

11. Seonghee, A.; Byungjoo K.; Eujin, H., Bull. Korean Chem. Soc. 2011, Vol.32, No.4, pp.1365-1367.

12. Siegfrid, K.; Heinz-Dieter, I.; Nils, L.; Erika, D.; Bernd, M.; Herbert, M.; Rolf, $\mathrm{H}_{\text {.; }}$ and Philippe, Q., Fresenius J Anal Chem, 2000, 368, 664-668.

13. SNI: $7313: 2008$, Maximum residue limit of pesticides in agricultural products (in Indonesian "Batas maksimum residu pestisida pada hasil pertanian") <https://www.scribd.com/doc/170144994/SNI -Batas-Maksimum-Pestisida>

14. Susana, G.; Stefan, H.; Penka, S.; John, S.; Berit, S.; Hakan, E.; Marta, D., Anal. Bioanal. Chem., 2015, 407: 3083-3091.

15. Sussane, B.; Ziyin, Y.; Tsuyoshi K.; Vo, A. T.; Nobuyuki, M.; Yoriyuki, N.; and Naoharu, W., American Journal of Analytical Chemistry, 2014, 5, 620-632.

16. Styarini, D.; Andreas; Ridwan, Y.S.; and Yusiasih, R.;, Indo. J. Chem., 2014, 14 (1), 12-21.

17. Thomas, P.J.L; Jean, P.; Adriaan, M.H. van deer Veen; Heinz, S.; and Andree, L., Accred Qual Assur, 2001, 6:20-25. 